OPEN ACCESS

Edited by:

Jade D'Alpoim Guedes, University of California, San Diego,

United States

Reviewed by:

Anke Hein

University of Oxford, United Kingdom

Vincenzo Amato,

University of Molise, Italy

*Correspondence:

Minmin Ma

mamm@/zu.edu.cn

Specialty section

This article was submitted to Quaternary Science, Geomorphology and Paleoenvironment, a section of the journal

Frontiers in Earth Science

Received: 31 January 2021 Accepted: 27 April 2021

Published: 19 May 2021

Citation:

LU M, LiX, Wei W, LUY, Ren L and Ma M (2021) Environmental Influences

on Human Subsistence Strategies in Southwest China During the Bronze Age: A Case Study at the Jiangxifen

Site in Yunnan

Front. Earth Sci. 9:662053.

doi: 10.3389/feart.2021.662053

\section{Environmental Influences on Human Subsistence Strategies in Southwest China During the Bronze Age: A Case Study at the Jiangxifen Site in Yunnan}

\author{
Minxia $\mathrm{Lu}^{1}$, Xiaorui $\mathrm{Li}^{2}$, Wenyu Wei ${ }^{1}$, Yiwen $\mathrm{Lu}^{1}$, Lele Ren ${ }^{3}$ and Minmin $\mathrm{Ma}^{1 *}$ \\ ${ }^{1}$ Key Laboratory of Western China's Environmental Systems (Ministry of Education), College of Earth and Environmental \\ Sciences, Lanzhou University, Lanzhou, China, ${ }^{2}$ Yunnan Provincial Institute of Cultural Relics and Archaeology, Kunming, \\ China, ${ }^{3}$ History and Culture School, Lanzhou University, Lanzhou, China
}

The study of human dietary structures is an effective means of elucidating the subsistence patterns of our prehistoric ancestors and can highlight the processes through which humans interacted with the environment. We conducted stable isotope and archeobotanical analyses of human, animal, and plant remains at the Jiangxifen site, dated to 900-400 BC, to explore human paleodiets and determine the environmental adaptation strategies adopted by humans in the middle valley of the Jinshajiang River in Yunnan Province. Humans predominantly consumed $\mathrm{C}_{4}$ foods (e.g., millet) and $\mathrm{C}_{4}$ food-fed animal protein sources, with smaller contributions from $\mathrm{C}_{3}$ food plants (e.g., rice) and $\mathrm{C}_{3}$ food-fed animal protein sources. We argued that the local dry-hot environment was the reason for the accessibility of $\mathrm{C}_{4}$ plants in the studied area. A comparison of our results with previously published archeobotanical data and isotopic evidence from human bones in other Bronze Age sites in Yunnan Province revealed high spatial variability in diets of human and subsistence strategies during this period. These differences were caused by the highly varying living environment of each region, which was related to fragmentation resulting from the geomorphological features of Yunnan Province.

Keywords: living environment, Bronze Age, subsistence strategy, human-land relationship, Jinshajiang River Valley

\section{INTRODUCTION}

In Eurasia, major changes in subsistence took place during the transition from the Neolithic to the Bronze Age (Dong et al., 2017; Hanks et al., 2018), changes that were profoundly impacted by the emergence and intensification of early trans-Eurasian exchanges (Svyatko et al., 2013; Dong et al., 2020). In East Asia, the transformation of human subsistence strategies was asynchronous during the Bronze Age. Exotic crops (wheat and barley) and livestock (sheep, cattle, etc.) encompassed the dominant forms of human subsistence in northwest China during the second millennium BC (Chen et al., 2015; Zhou et al., 2016; Dong et al., 2021), whereas indigenous millet cultivation dominated in the Central Plains of North China until the late first millennium BC (Li et al., 2020). However, the spatial pattern of means of human livelihood in Yunnan Province in Southwest China, another important region for transcontinental exchange during the Bronze Age (Gao et al., 2020), remains unclear. 
Archeobotanical, zooarcheological, and stable isotope analyses are effective methods for studying human subsistence strategies during prehistoric periods (d'Alpoim Guedes et al., 2014; Ma et al., 2016; Ren et al., 2020). Archeobotany and zooarcheology encompass systematic studies aimed at elucidating animal and plant exploitation strategies (Isaakidou and Halstead, 2018). However, the acidic soils in Yunnan Province are unsuitable for macro-fossil preservation, and the animals buried in tombs might not be representative of the prevalent fauna (Yuan, 2015; Hou et al., 2019); this prevents the study of prehistoric subsistence strategies in this area. Stable isotope analysis can be used to reconstruct the diet structure of humans and animals (Kohn, 1999; Richards, 2015), but it only yields $\mathrm{C}_{3} / \mathrm{C}_{4}$ signals, rather than elucidating specific food types. Therefore, it is necessary to combine a variety of methods to comprehensively reconstruct human subsistence strategies in prehistoric times. Archeobotanical and stable isotope analyses for Bronze Age sites in Yunnan are particularly scarce, with only limited evidence from a small number of sites, such as Dayingzhuang (Dal Martello et al., 2021), Haimenkou (Xue, 2010), Shilinggang (Li et al., 2016; Ren et al., 2017), Jinlianshan-Xueshan (Zhang, 2011; Wang, 2014), and Mayutian (Zhang et al., 2014). Therefore, our current understanding of subsistence during the Bronze Age in this region is limited. Yunnan province is geographically highly diverse and is characterized by the presence of large mountain chains and deeply cut rivers in the eastern margin of the Tibetan Plateau. Deep river valleys which include the valleys of the Lancangjiang, Nujiang, and Jinshajiang Rivers, and large lakes characterize this landscape.

In the present study, we analyzed the stable carbon (C) and nitrogen $(\mathrm{N})$ isotopes of human and animal bones and identified plant remains from the Jiangxifen Bronze Age site, which is located in the Jinshajiang River Valley. We also conducted radiocarbon dating at the site to reconstruct the diets of ancient locals. These results were also compared with previously published data from contemporaneous sites in Yunnan Province to explore the spatial patterning in ancient human diets and their relationship with the local environment. Our study findings contribute to our understanding of past human-land relationships in Southwest China during the Bronze Age before the region was controlled by a unified regime.

\section{STUDY AREA}

Yunnan province is located in the low latitude plateau, and it is mainly dominated by the Indian summer monsoon and East Asian summer monsoon (Cao et al., 2012). The temperature in January is about $9-11^{\circ} \mathrm{C}$, and in July is about $22^{\circ} \mathrm{C}$. The annual mean precipitation is $1,100-1,600 \mathrm{~mm}$ (Shi and Chen, 2018). However, the local climate in Yunnan is diverse owing to the presence of many rivers and high mountains. In different valleys, rain shadows can lead to drier and hotter conditions.

The Jiangxifen site $\left(26.18^{\circ} \mathrm{N}\right.$ and $\left.102.23^{\circ} \mathrm{E}\right)$ is located in Jiyi town, Wuding County, Yunnan Province (Figure 1). The site is in the Jinshajiang River Valley with dry and megathermal climate, the annual average temperature and the $\geq 10^{\circ} \mathrm{C}$ accumulated temperature are $21.5^{\circ} \mathrm{C}$ and $7,400^{\circ} \mathrm{C}$, respectively, and the annual precipitation is $\leq 630 \mathrm{~mm}$ (Yang, 2006). Shrubs and the Savanna shrubs dominate below $1,700 \mathrm{~m}$ in this valley (Jin and Ou, 2000; Zhang et al., 2005), and the coniferous forest is mainly distributed above $1,700 \mathrm{~m}$. The Jinshajiang River flows through the study area from southwest to northeast, and the site is located on the second fluvial terrace at the south bank of the Jinshajiang River with an altitude of $900 \mathrm{~m}$. The terrain of the region is complex and highly fragmented due to geomorphic uplift and erosion (Nie et al., 2008). High mountains flank the east and west sides of the river. Red sandstone is exposed and geological disasters occur frequently. Modern plant vegetation surveys (Cao and Jin, 1989; Ou, 1994; Jin, 1999; Li et al., 2009) have indicated that a large amount of $\mathrm{C}_{4}$ vegetation is distributed in the dry-hot valley of the Jinshajiang River. Analyses of pollen assemblages (Xiao et al., 2014, 2018, 2020; Zheng et al., 2014) and the stable $\mathrm{C}$ isotopes $\left({ }^{13} \mathrm{C}\right)$ of long-chain $n$-alkanes from sediments (Cui et al., 2015, 2019) indicated the existence of a forest in Yunnan Province during the late Holocene (after $3,300 \mathrm{BP})$.

In total, 530 tombs were identified during the excavation of the Jiangxifen site in the period from November 2018 to April 2019. The characteristics of the unearthed cultural relics and funeral objects from the site are indicative of the Bronze Age (Yunnan Institute of Cultural Relics and Archaeology, 2019).

\section{MATERIALS AND METHODS}

\section{Collagen Preparation and Isotope Analysis}

In total, 74 human and 35 animal bone samples were collected from the Jiangxifen site. Of these, 68 human and three animal bone collagen samples were extracted (Supplementary Table 1).

Bone collagen was extracted at the Key Laboratory of Western China's Environmental Systems (MOE), Lanzhou University, Gansu Province, China. Based on the method described by Richards and Hedges (1999), we placed $0.5-1.5 \mathrm{~g}$ of bones in $0.5 \mathrm{~mol} / \mathrm{L} \mathrm{HCl}$ and $0.125 \mathrm{~mol} / \mathrm{L} \mathrm{NaOH}$ to remove inorganic matter and humic acids, respectively. The bones were then placed in a weakly acidic solution $(\mathrm{pH}=3)$ for acidification and subsequently filtered and freeze-dried to obtain collagen.

The $\mathrm{C}$ and $\mathrm{N}$ percentages in the five collagen samples were measured using the Elementar Vario EL Cube elemental analyzer (Elementar Analysensysteme GmbH, Germany) at the State Key Laboratory of Applied Organic Chemistry, Lanzhou University. Isotope analysis was conducted using the Thermo Fisher Flash EA1112-MAT253 mass spectrometer (Thermo Fisher Scientific, Germany) at the Key Laboratory of Western China's Environmental Systems (MOE), Lanzhou University. Sixty-six collagen samples were examined using an IsoPrime100 IRMS mass spectrometer combined with a vario PYRO cube elemental analyzer (Elementar, Germany) at the archaeological stable isotope laboratory, the University of Chinese Academy of Sciences. The $\mathrm{C}$ and $\mathrm{N}$ isotope ratios were expressed as $\delta^{13} \mathrm{C}$ and $\delta^{15} \mathrm{~N}$, relative to the international standards $\mathrm{V}-\mathrm{PDB}$ and AIR, respectively. The isotopic analytical precision was $0.2 \%$. 


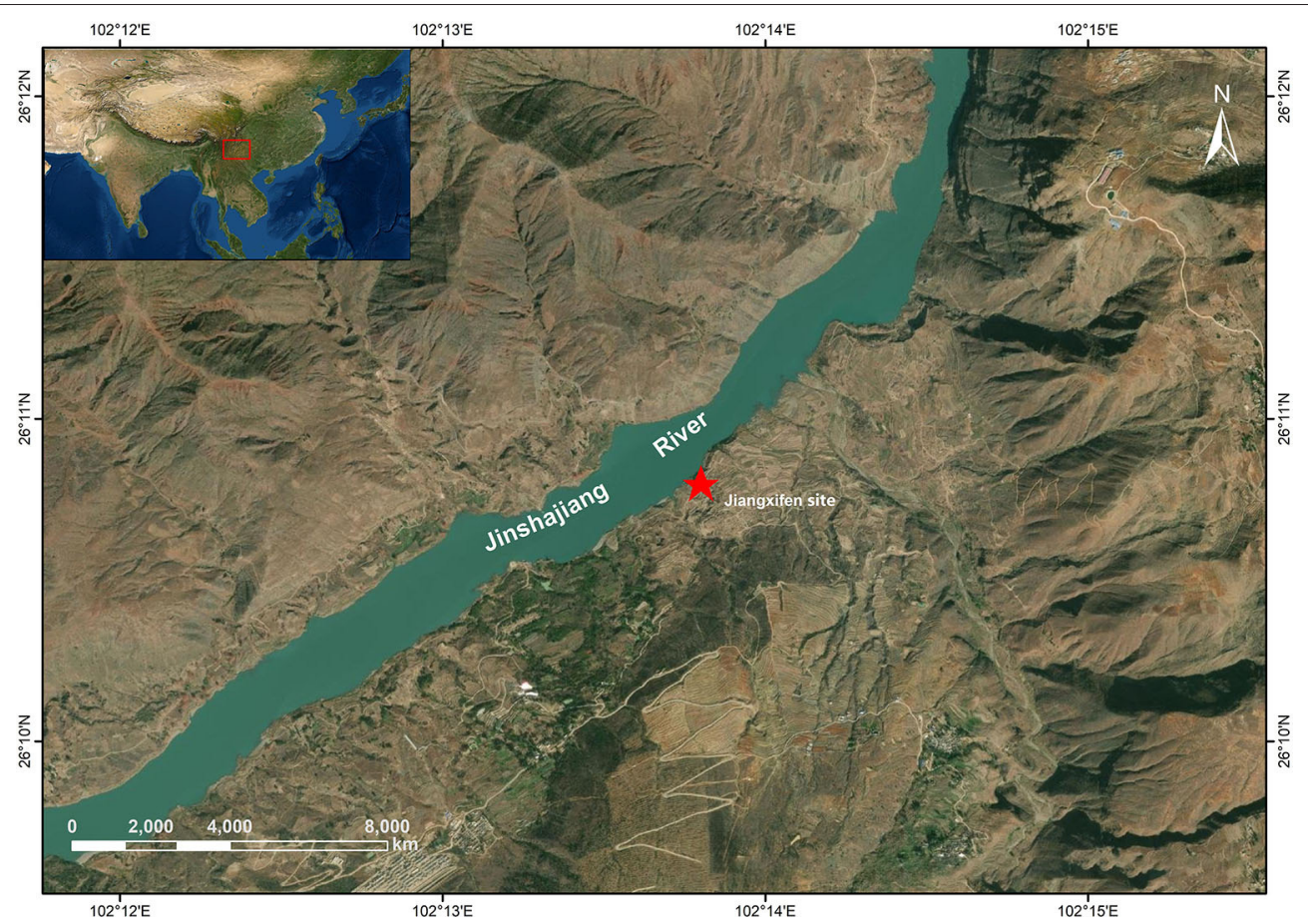

FIGURE 1 | Location of the Jiangxifen site.

TABLE 1 | Radiocarbon dates at the Jiangxifen site.

\begin{tabular}{|c|c|c|c|c|c|}
\hline Lab no. & Context & Sample no. & Species & ${ }^{14} \mathrm{C}$ date BP & Calibrated age BC/AD (95.4\% prob.) \\
\hline Beta-547362 & 2018YnJM205-1 & $\mathrm{R}-15$ & Human bone & $2,660 \pm 30$ & $899 \mathrm{cal} \mathrm{BC} \sim 790 \mathrm{cal} \mathrm{BC}$ \\
\hline Beta-544140 & 2018YnJM230 & $\mathrm{R}-34$ & Human bone & $2,560 \pm 30$ & $805 \mathrm{cal} \mathrm{BC} \sim 563 \mathrm{cal} \mathrm{BC}$ \\
\hline LZU19287 & 2018YnJM199 & $\mathrm{R}-12$ & Human bone & $2,560 \pm 30$ & $805 \mathrm{cal} \mathrm{BC} \sim 563 \mathrm{cal} \mathrm{BC}$ \\
\hline Beta-544139 & 2018YnJM207 & $\mathrm{R}-17$ & Human bone & $2,550 \pm 30$ & $801 \mathrm{cal} \mathrm{BC} \sim 550 \mathrm{cal} \mathrm{BC}$ \\
\hline Beta-544141 & 2018YnJM270 & $\mathrm{R}-62$ & Human bone & $2,540 \pm 30$ & $796 \mathrm{cal} \mathrm{BC} \sim 547 \mathrm{cal} \mathrm{BC}$ \\
\hline LZU19288 & 2018YnJM204-1 & $\mathrm{R}-13$ & Human bone & $2,530 \pm 30$ & $794 \mathrm{cal} \mathrm{BC} \sim 544 \mathrm{cal} \mathrm{BC}$ \\
\hline Beta-547363 & 2018YnJM249 & $R-45$ & Human bone & $2,520 \pm 30$ & $789 \mathrm{cal} \mathrm{BC} \sim 544 \mathrm{cal} \mathrm{BC}$ \\
\hline Beta-544137 & 2018YnJM217 & D-37 & Bovid bone & $2,480 \pm 30$ & $772 \mathrm{cal} \mathrm{BC} \sim 476 \mathrm{cal} \mathrm{BC}$ \\
\hline LZU19289 & T3503(7) & $\mathrm{D}-27$ & Pig bone & $2,470 \pm 30$ & $766 \mathrm{cal} \mathrm{BC} \sim 422 \mathrm{cal} \mathrm{BC}$ \\
\hline
\end{tabular}

\section{Radiocarbon Dating}

Seven human and two animal collagen samples were selected for accelerated mass spectrometry radiocarbon dating at Peking University, Beijing; and at Beta Analytic Inc., Florida, United States (Table 1). The ${ }^{14} \mathrm{C}$ dates were calibrated using Oxcal version 4.4.2 (Ramsey, 2017) with the IntCal20 curve (Reimer et al., 2020) and reported as "cal BC."

\section{Plant Remains}

About 17 samples of plant remains were collected via flotation sampling from soil (a total of $194 \mathrm{~L}$ ). Three flotation samples were collected from the ash pits, and 14 flotation samples were collected from the cultural layers. Plant identification was carried out at the key laboratory of Western China's environmental systems (MOE), Lanzhou University.

\section{RESULTS}

\section{Chronology}

The radiocarbon dating results are presented in Table 1. The Jiangxifen site was dated to $899-422$ cal BC, with a range of 95.4\%. This period covers the middle Western Zhou Dynasty $(1,046-771 \mathrm{BCE})$ to the early Warring States Period (475-221 $\mathrm{BC})$ in the Central Plains.

\section{Isotope Analysis}

The isotope data for human and animal bone collagen are presented in Supplementary Table 1, Table 2, Figure 2. The collagen of C:N ratios ranged from 3.1 to 5.7, with yields of $0.1-4.7 \%$. Three human collagen samples were poorly preserved and excluded from further analyses, as their C:N ratios were outside the range of 2.9-3.6 
TABLE 2 | Summary of results of $\mathrm{C}$ and $\mathrm{N}$ isotopes for humans and animals at the Jiangxifen site.

\begin{tabular}{|c|c|c|c|c|c|c|c|}
\hline \multirow[t]{2}{*}{ Species } & \multirow[t]{2}{*}{ Number } & \multicolumn{3}{|c|}{$\delta^{13} \mathrm{C}(\%)$} & \multicolumn{3}{|c|}{$\delta^{15} \mathrm{~N}(\%)$} \\
\hline & & Mean & SD & Range & Mean & SD & Range \\
\hline Human & 65 & -14.2 & 1.6 & $-18.6 \sim-9.4$ & 9.8 & 1.0 & $5.9 \sim 12.4$ \\
\hline Pig & 2 & -19.5 & 2.3 & $-21.1 \sim-17.8$ & 6.2 & 1.6 & $5.1 \sim 7.3$ \\
\hline Bovid & 1 & -8.1 & - & -8.1 & 4.6 & - & 4.6 \\
\hline
\end{tabular}

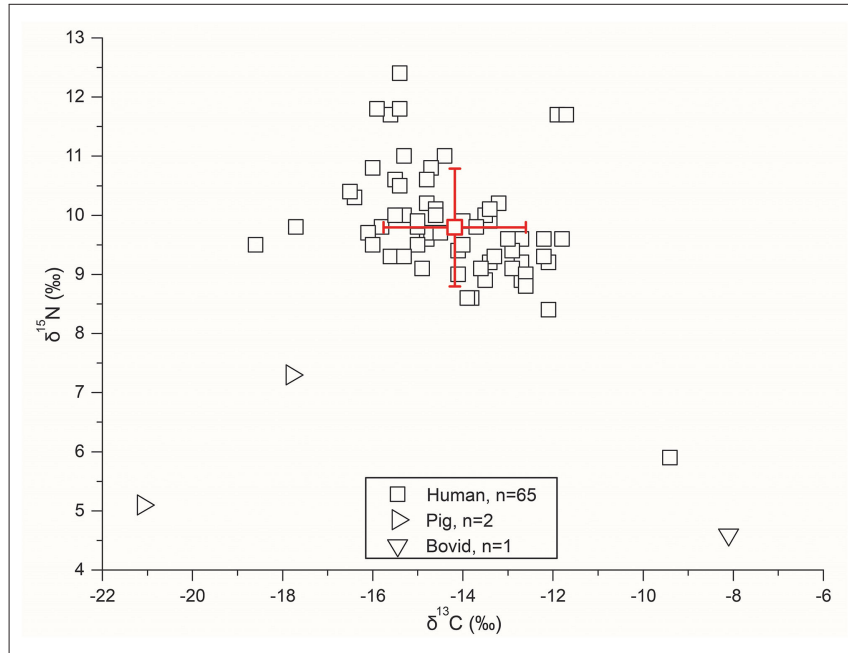

FIGURE 2 | Scatter diagram of carbon (C) and nitrogen (N) isotopes values for human and animal bone collagen.

(DeNiro, 1985; Ambrose, 1990). In addition, samples with a yield $<1 \%$ and with $\mathrm{C}: \mathrm{N}$ ratios between 2.9 and 3.6 were considered to be well-preserved and conformed to the analytic standard.

The $\delta^{13} \mathrm{C}$ and $\delta^{15} \mathrm{~N}$ values of human collagen $(n=65)$ ranged from -18.6 to $-9.4 \%$ o (mean $=-14.2 \pm 1.6 \%$ ) and from 5.9 to $12.4 \%$ o (mean $=9.8 \pm 1.0 \%$ ), respectively. The $\delta^{13} \mathrm{C}$ and $\delta^{15} \mathrm{~N}$ values of pig collagen $(n=2)$ ranged from -21.1 to $-17.8 \%$ o $($ mean $=-19.5 \pm 2.3 \%$ o $)$ and from 5.1 to $7.3 \%$ (mean $=6.2 \pm$ $1.6 \%$ ), respectively. Only one bovid bone collagen was extracted, and its $\delta^{13} \mathrm{C}$ and $\delta^{15} \mathrm{~N}$ values were $-8.1 \%$ and $4.6 \%$, respectively (Table 2).

\section{Plant Remains}

Although we collected a total of 17 flotation samples, only a few plant macrofossils were identified from the ash pits. In total, 203 charred plant seeds were identified. The identified crop remains included eight caryopses of foxtail millet (Setaria italica), three caryopses of common millets (Panicum miliaceum), 83 whole rice seeds (Oryza sativa), and 107 broken rice seeds, as shown in Table 3, Figure 3. We also identified the remains of two wild plant species: the three-horned bedstraw (Galium tricornutum) and lambsquarters (Chenopodium album L.).

\section{DISCUSSION}

\section{Human Diets and Subsistence at the Jiangxifen Site During the Period 900-400 BC}

Natural vegetation surveys (Cao and Jin, 1989; Ou, 1994; Jin, 1999; Ward et al., 1999; Nelson et al., 2004; Li et al., 2009) and analyses of $\delta^{13} \mathrm{C}$ values in the Holocene sediments (Cui et al., 2015 , 2019) indicated that $C_{4}$ plants have an advantage in the hot and dry climate of the Jinshajiang River Valley in both modern times and throughout the Holocene. In contrast, $C_{3}$ vegetation dominates the higher altitude. Therefore, we urge caution in the interpretation of the $\mathrm{C}_{4}$ signal in humans and animals in this region, even though in North China, $\mathrm{C}_{3}$ food resources in human diets are typically associated with wheat and rice, whereas $\mathrm{C}_{4}$ resources are typically associated with millet (Zhang et al., 2015; Zhou and Garvie-Lok, 2015; Ma et al., 2016; Cheung et al., 2019). Evidence from charred plants at the Baiyangcun site revealed that the earliest rice and foxtail millet remains in Yunnan were dated between 2,624-2,475 cal BC and 2,868-2,573 cal BC, respectively (Dal Martello et al., 2018). In Yunnan, wheat was cultivated later, with the earliest occurrence dated to 3,125 $\pm 30 \mathrm{BP}$, as determined in the second phase of the Haimenkou site (Xue, 2010). However, both rice and millet accounted for a certain proportion of plant food sources in the dry-hot valley of the Jinshajiang River during the prehistoric period; this is supported by evidence from unearthed plant remains from the Dadunzi and Baiyangcun sites (Jin et al., 2014; Dal Martello et al., 2018), as well as those from the Jiangxifen site in the present study (Figure 3).

Animal isotope data are typically used to explain human isotope values for the reconstruction of human diets. In the present study, the average $\delta^{13} \mathrm{C}$ value for the two pigs $(-19.5$ $\pm 2.3 \%$ ) indicated a predominately $\mathrm{C}_{3}$ food-based diet, which suggested either that the pigs foraged or were captured in the high-altitude forests or that humans fed them $\mathrm{C}_{3}$ food (e.g., $\mathrm{C}_{3}$ plants, rice by-products etc.; Table 2, Figure 2). The $\delta^{13} \mathrm{C}$ value for single bovid $\left(-8.1 \%\right.$ ) indicated a $\mathrm{C}_{4}$ plant-based diet, which suggested that the bovid might have been fed $\mathrm{C}_{4}$ plants by humans, as the natural vegetation in the dry-hot valley included both $\mathrm{C}_{3}$ and $\mathrm{C}_{4}$ vegetation (Table 2, Figure 2).

The $\delta^{13} \mathrm{C}$ and $\delta^{15} \mathrm{~N}$ values for humans $(n=65)$ ranged from -18.6 to $-9.4 \%$ (mean $=-14.2 \pm 1.6 \%$ ) and from 5.9 to $12.4 \%$ o $($ mean $=9.8 \pm 1.0 \%$ o , respectively, indicating a range of $\mathrm{C}_{4}$, mixed $\mathrm{C}_{3} / \mathrm{C}_{4}$, and mainly $\mathrm{C}_{4}$ diets (Table 2 , Figure 2). The wide range of human $\delta^{13} \mathrm{C}$ values implies the use of highly varying food resources. However, the $\delta^{13} \mathrm{C}$ values 
TABLE 3 | Number of identified samples of charred seeds from the flotations at the Jiangxifen site.

\begin{tabular}{|c|c|c|c|c|c|c|c|}
\hline $\begin{array}{l}\text { Sample } \\
\text { No. }\end{array}$ & $\begin{array}{l}\text { Soil flotation } \\
\text { quantity(L) }\end{array}$ & $\begin{array}{l}\text { Setaria } \\
\text { italica }\end{array}$ & $\begin{array}{l}\text { Panicum } \\
\text { miliaceum }\end{array}$ & $\begin{array}{l}\text { Oryza sativa } \\
\text { (Whole) }\end{array}$ & $\begin{array}{c}\text { Oryza sativa } \\
\text { (Broken) }\end{array}$ & $\begin{array}{l}\text { Galium } \\
\text { tricornutum } \\
\text { Dandy }\end{array}$ & $\begin{array}{c}\text { Chenopodium } \\
\text { album } L .\end{array}$ \\
\hline
\end{tabular}

\begin{tabular}{lcccccc}
\hline T3101 H12 & 10 & 7 & 3 & - & - & - \\
H6 & 7.3 & 1 & - & 83 & - & 107 \\
H4 & 10 & - & - & - & - & - \\
Total & 27.3 & 8 & 3 & 83 & 107
\end{tabular}

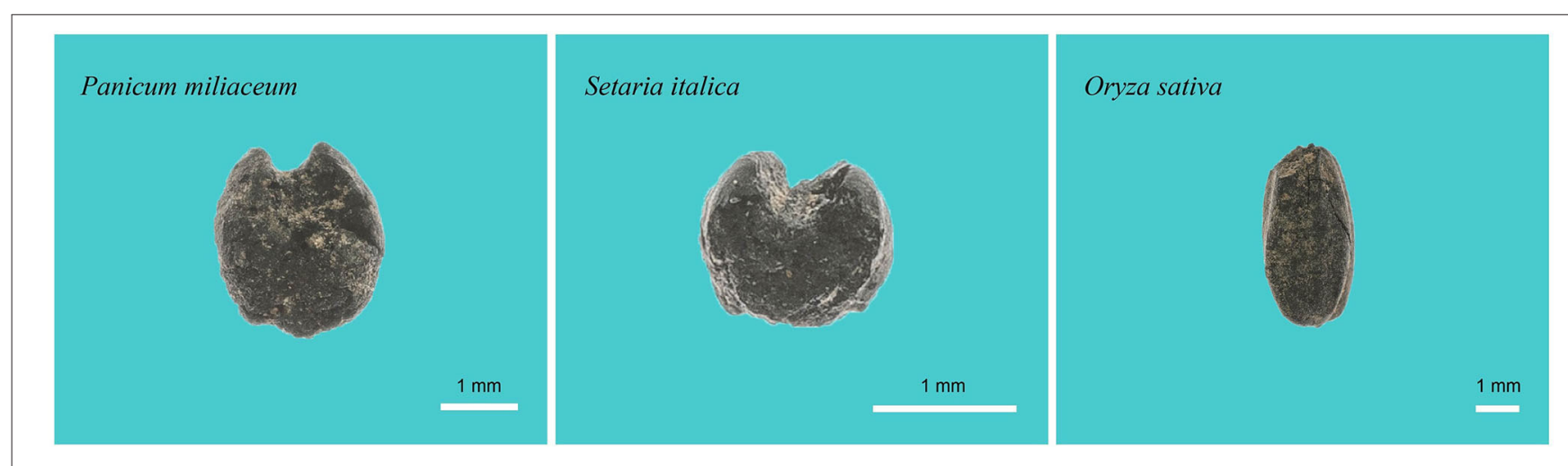

FIGURE 3 | Remains of crops identified at the Jiangxifen site.

for most individuals (60 out of 65 ) demonstrated mixed $\mathrm{C}_{3} / \mathrm{C}_{4}$ diets, implying the predominant consumption of both $\mathrm{C}_{3}$ and $\mathrm{C}_{4}$ foods. Furthermore, the average human $\delta^{13} \mathrm{C}$ value $(-14.2$ $\pm 1.6 \%$ ) indicated a preference for $\mathrm{C}_{4}$ foods; however, a single individual consumed a significant amount of $\mathrm{C}_{3}$ foods. Moreover, the $\delta^{13} \mathrm{C}$ values for four individuals indicated a predominance of $\mathrm{C}_{4}$ foods. As the plant remains from this and other sites in the region indicated that millet and rice were the staple plant foods during the Bronze Age, we assumed that the $\mathrm{C}_{3}$-consuming humans mainly relied on rice and $\mathrm{C}_{3}$ food-fed animal protein, and so on, whereas the $\mathrm{C}_{4}$-consuming humans mainly relied on millet and $\mathrm{C}_{4}$ food-fed animal protein, and so on. Consumers of both $\mathrm{C}_{3}$ and $\mathrm{C}_{4}$ foods likely relied on both $\mathrm{C}_{3}$ (rice, $\mathrm{C}_{3}$ food-fed animal protein, etc.) and $\mathrm{C}_{4}$ (millet, $\mathrm{C}_{4}$ food-fed animal protein, etc.) foods. Undoubtedly, all humans likely foraged for both $\mathrm{C}_{3}$ and $\mathrm{C}_{4}$ plant foods in the wild, but wild plant consumption was probably limited owing to the prevalence of mixed millet and rice agriculture in Jiangxifen. Overall, humans at the Jiangxifen site might have preferred to consume $\mathrm{C}_{4}$ foods, implying the predominance of millet agriculture.

The occurrence of mixed millet and rice agriculture in the region suggested the potential adaptation of humans to the specific environment of the dry-hot valley. The river valley is suitable for rice agriculture because this crop requires considerable amounts of water. In contrast, the hillside far away from the river is suitable for millet agriculture, as dry conditions are preferable for the cultivation of this crop. Furthermore, ancient humans likely relied on millet agriculture because the Jinshajiang River Valley was predominantly hot and dry, with only a limited area on the waterfront suitable for rice production.
Nitrogen isotopes are typically used to measure protein consumption (Hu et al., 2008; Ma et al., 2015; Cheung et al., 2017). The $\delta^{15} \mathrm{~N}$ value for humans at the Jiangxifen site ranged from 5.9 to $12.4 \%$, indicating diverse protein sources. The shift of $5.2 \%$ in the mean $\delta^{15} \mathrm{~N}$ value between humans and herbivores suggested that humans may have consumed a large amount of animal protein, including fish from the Jinshajiang River. However, only one bovid collagen sample was available to assess the human consumption of animal protein in the present study; therefore, future studies should also assess herbivore $\delta^{15} \mathrm{~N}$ values to confirm our findings.

\section{Spatial Pattern of Human Subsistence Strategies and Influencing Factors Thereof in Yunnan Province During the Bronze Age}

To study the spatial pattern of human subsistence strategies in different environments of Yunnan, we compared the isotopic evidence at the Shilinggang, Jinlianshan, and Jiangxifen sites, all of which have similar chronologies (Zhang, 2011; Liu, 2016; Ren et al., 2017). The average $\delta^{13} \mathrm{C}$ value for human bones at the Shilinggang site $(-18.7 \pm 0.9 \%$ ) was significantly more negative than that at the Jiangxifen site $(p=0.000$, Table 4$)$, indicating a higher consumption of $\mathrm{C}_{3}$ foods. According to the archeobotanical studies carried out at Shilinggang (Li et al., 2016; Zhang et al., 2017), humans cultivated both rice and millets, as well as some plants with underground storage organs, such as tubers, roots, and rhizomes. The annual average temperature and precipitation at the Shilinggang site are $\sim 21^{\circ} \mathrm{C}$ and $1,100-$ $1,200 \mathrm{~mm}$, respectively (Li et al., 2016); thus, the climate of this 
TABLE 4 | Comparison of results of the human bone collagen isotope from archaeological sites in Yunnan.

\begin{tabular}{|c|c|c|c|c|c|c|c|}
\hline \multirow[t]{2}{*}{ Site } & \multirow[t]{2}{*}{ Age } & \multirow[t]{2}{*}{ Number } & \multicolumn{2}{|c|}{$\delta^{13} \mathrm{C}(\%)$} & \multicolumn{2}{|c|}{$\delta^{15} \mathrm{~N}(\%)$} & \multirow[t]{2}{*}{ References } \\
\hline & & & Average & Range & Average & Range & \\
\hline Jiangxifen & $\sim 900 \sim 400 \mathrm{BC}$ & 65 & $-14.2 \pm 1.6 \%$ & $-18.6 \%$ -9.4\%о & $9.8 \pm 1.0 \%$ & $5.9 \%$ 12.4\% & This study \\
\hline Shilinggang & $\sim 950 \sim 350 \mathrm{BC}$ & 48 & $-18.7 \pm 0.9 \%$ & $-20.0 \%$ -14.9\% & $9.7 \pm 1.5 \%$ & $3.9 \%$ 11.9\% & $\begin{array}{l}\text { Li et al., 2016; Liu, 2016; Ren et al., } \\
2017\end{array}$ \\
\hline Jinlianshan & $\sim 500 \mathrm{BC} \sim 220 \mathrm{AD}$ & 9 & $-18.8 \pm 0.4 \%$ & $-19.3 \%$ -18.2\%о & $9.8 \pm 0.9 \%$ & $8.8 \%$ 11.4\% & Zhang, 2011 \\
\hline
\end{tabular}

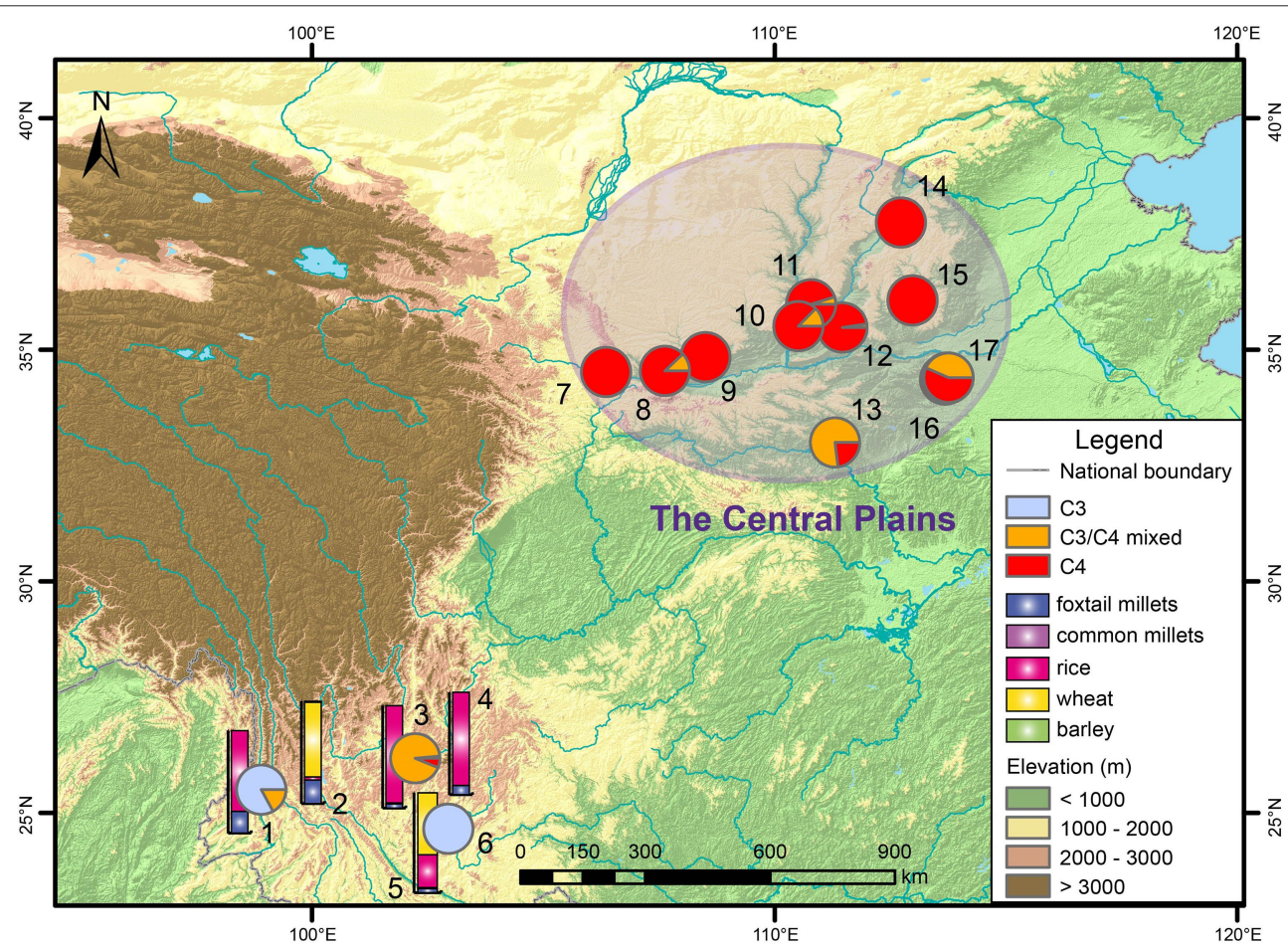

FIGURE 4 | Comparison of human $\mathrm{C}$ isotope values and frequency index of the crop remains at the Jiangxifen site and other contemporaneous sites in Yunnan (Xue, 2010; Zhang, 2011; Wang, 2014; Yao et al., 2015; Li and Liu, 2016; Li et al., 2016; Liu, 2016; Yang, 2016; Ren et al., 2017; Dal Martello et al., 2021) and the Central Plains (Pei et al., 2008; Ling et al., 2010a,b; Chen, 2012; Hou et al., 2012; Dong et al., 2017; Lan, 2017; Zhou et al., 2017; Tang et al., 2018; Sun, 2019; Li et al., 2020): (1) Shilinggang; (2) Haimenkou; (3) Jiangxifen; (4) Yubeidi; (5) sites around Dian and Fuxianhu Lake (including Dayingzhuang, Hebosuo, Anjiang, Xiaogucheng, Guangfentou, and Xueshan); (6) Jinlianshan; (7) Jianhe; (8) Sunjianantou; (9) Zaoshugounao; (10) Liangdaicun; (11) Neiyangyuan; (12) Hengshui; (13) Shenmingpu; (14) Xiaonanzhuang; (15) Xinancheng; (16) Changxinyuan; and (17) Xiyasi.

site is wetter and cooler than that of Jiangxifen. Accordingly, humans mainly consumed $\mathrm{C}_{3}$ foods, with a little supplement from $\mathrm{C}_{4}$ foods (likely millets). The age of the Jinlianshan site overlaps with that of the Jiangxifen site (Jiang and $\mathrm{Wu}, 2011$ ). The $\delta^{13} \mathrm{C}$ value for the human bone collagen at the Jinlianshan site was found to range from -19.3 to $18.2 \%$, suggesting that humans mainly consumed $\mathrm{C}_{3}$ foods. This finding is significantly different from the findings at the Jiangxifen site $(p=0.000$, Table 4). Unearthed plant remains from the Xueshan site (which is located near the Jinlianshan site and has a similar chronology) indicated that humans cultivated wheat, rice, barley, and millets in that area (Wang, 2014). Wheat and rice were the main crops at the Jinlianshan site. The $\delta^{13} \mathrm{C}$ values obtained from enamel samples at the Shamaoshan site, a contemporaneous site near the
Jinlianshan site, also suggested that humans mainly consumed $\mathrm{C}_{3}$ foods in this area (Wu et al., 2019). In contrast to the hot-dry valley of the Jinshajiang River, the Jinlianshan and Shamaoshan sites are located in lake basins and are therefore more humid, indicating that there were sufficient water sources for wheat and rice cultivation.

Previous archeobotanical research has revealed differences in agricultural practices among various regions of Yunnan (Figure 4). The number of wheat seeds identified during the third phase of the Haimenkou site accounted for $73 \%$ of the total number of seeds from unearthed crops (Xue, 2010). In contrast, no wheat seeds were unearthed at the Jiangxifen, Shilinggang, and Yubeidi sites during the same period. Rivers and lakes with abundant water were convenient for imported 
wheat agriculture (Xue, 2010). Moreover, the high mountains and deep valleys in Yunnan may have hindered human migration and cultural exchanges among different regions during the Bronze Age. This may have been the main reason for the lack of wheat remains at the Jiangxifen and Shilinggang sites. Wheat and rice were the main crops in the sites around Dian and Fuxian lakes (Figure 4). The terrain around Dian and Fuxian lakes is flat, and the water resources are sufficient for wheat and rice cultivation.

Furthermore, tomb types and artifact assemblages unearthed from the Bronze Age sites in different regions of Yunnan Province exhibited different characteristics (Fan, 2007). These characteristics can be used to divide Yunnan into multiple cultural regions (He, 2003; Ao, 2015), further highlighting the effect of the fragmented landscape on cultural evolution (including dietary patterns) of humans during the Bronze Age. Casting processes, vessel types, and patterns of bronze ware differed among cultural regions (Fan, 2007). For example, the bronze wares unearthed in the sites around Dian Lake have complex casting techniques and diverse patterns, whereas the bronze wares from the Erhai Lake have simple casting techniques and fewer patterns. The bronze wares unearthed in northwest Yunnan have a considerable relationship with North China (Fan, 2007). In addition, the tomb type at the Wanjiaba site, which is a site near Dian Lake, is completely different from the tomb type in northwest Yunnan (He, 2003).

In contrast to the spatial heterogeneity of human livelihoods in Yunnan, the Zhou Dynasty sites in the Central Plains $(\sim 1,046-256 \mathrm{BC})$ are revealed by isotopic evidence to have homogenous spatial characteristics in terms of human diet and subsistence (Figure 4). Millet crops were generally the dominant food source, whereas other crops, including wheat, rice, and soybean, were complementary food sources (Zhao, 2014; Zhou et al., 2017; Tao et al., 2020). As shown in Figure 4, the C isotopes of human bones from Zhou Dynasty sites in the Central Plains indicated that most individuals consumed $\mathrm{C}_{4}$ foods (likely millets and their by-products), with only a small number of individuals consuming mixed $\mathrm{C}_{4}$ and $\mathrm{C}_{3}$ foods. The differences in human dietary patterns between Yunnan and the Central Plains might have been caused by the diversity of geomorphological features. Yunnan is located on the Yunnan-Guizhou Plateau; this terrain is high in the northwestern part and low in the southeastern part, with great undulations. The presence of large rivers, alternating mountains, and valleys is the reason for the high terrain fragmentation in Yunnan (Nie et al., 2008). Geomorphological features in the Central Plains are significantly different from those in Yunnan Province. Although the landform types in the Central Plains are complex, with high mountains and large plains, archeological sites are mostly distributed in the flat river valley areas (Figure 4). Stream networks in the middle reaches of the Yellow River facilitated human migration and cultural communication among different geographical units, and the area was controlled by a nominally unified regime (the Zhou Imperial Court). For this reason, human subsistence practice was based primarily on millet cultivation. The same social phenomenon did not occur in Yunnan until more recent historical periods; however, it is unclear whether the spatial pattern of subsistence also transformed synchronously. Therefore, this topic should be investigated further in future studies.

\section{CONCLUSIONS}

Based on $\mathrm{C}$ and $\mathrm{N}$ isotopic results and archeobotanical evidence, we concluded that humans in the Jiangxifen site consumed both $\mathrm{C}_{3}$-based (rice and $\mathrm{C}_{3}$ food-fed animal protein) and $\mathrm{C}_{4^{-}}$ based food (millet and $\mathrm{C}_{4}$ food-fed animal protein) during the period of $\sim 900-400 \mathrm{BC}$, with a preference for $\mathrm{C}_{4}$-based food. The local environment in the dry-hot valley of the Jinshajiang River provided favorable conditions for millet and rice growth, which was the primary factor influencing food choice in this valley. When we compared our results with previously published isotopic data and archeobotanical evidence in contemporaneous sites of Yunnan Province, we were able to identify notable spatial discrepancies in human livelihoods in the Bronze Age in Yunnan. In this period, various crops and livestock were introduced to Yunnan Province; however, the highly fragmented geomorphological setting of the region significantly hindered trans-regional exchange. Therefore, prior to the development of a strong transportation network, local environmental settings (especially hydrothermal conditions) had a significant impact on local human diets and livelihoods in different parts of Yunnan Province.

\section{DATA AVAILABILITY STATEMENT}

The original contributions presented in the study are included in the article/Supplementary Material, further inquiries can be directed to the corresponding author/s.

\section{AUTHOR CONTRIBUTIONS}

MM and ML: formal analysis and writing and editing. MM: funding acquisition and supervision. XL: resources. WW, YL, and LR: sample collection. ML, WW, YL, and LR: methodology. All authors contributed to the article and approved the submitted version.

\section{FUNDING}

This research was supported by the Strategic Priority Research Program of Chinese Academy of Sciences, the Pan-Third Pole, the Environment Study for a Green Silk Road (Pan-TPE) (Grant No. XDA20040101), the Major Program of the National Natural Science Foundation of China (Grant No. 41991251), and the National Natural Science Foundation of China (Grant No. 41871076).

\section{SUPPLEMENTARY MATERIAL}

The Supplementary Material for this article can be found online at: https://www.frontiersin.org/articles/10.3389/feart. 2021.662053/full\#supplementary-material 


\section{REFERENCES}

Ambrose, S. H. (1990). Preparation and characterization of bone and tooth collagen for isotopic analysis. J. Archaeol. Sci. 17, 431-451. doi: 10.1016/0305-4403(90)90007-R

Ao, S. (2015). On early Bronze culture in Yunnan (in Chinese with English Abstract). Master's thesis Yunnan. Yunnan University.

Cao, J., Hu, J. M., and Tao, Y. (2012). An index for the interface between the Indian summer monsoon and the East Asian summer monsoon. J. Geophys. Res. Atmos. 117:D18108. doi: 10.1029/2012JD017841

Cao, M., and Jin, Z. Z. (1989). Classification of vegetation in Qiaojia dry-hot rier valley of Jinsha river, Yunnan (in Chinese). Acta Botanica Yunnanica $11,324-336$.

Chen, F. H., Dong, G. H., Zhang, D. J., Liu, X. Y., Jia, X., An, C. B., et al. (2015). Agriculture facilitated permanent human occupation of the Tibetan Plateau after 3600 BP. Science 347, 248-250. doi: 10.1126/science.1259172

Chen, X. (2012). Study on the bone chemistry characteristics of human bones unearthed in the Western Zhou Dynasty from Ruiguo Cemetery in Liangdai Village (in Chinese with English Abstract). [master's thesis] [Shaanxi]: Northwestern University.

Cheung, C., Jing, Z. C., Tang, J. G., Weston, D. A., and Richards, M. P. (2017). Diets, social roles, and geographical origins of sacrificial victims at the royal cemetery at Yinxu, Shang China: new evidence from stable carbon, nitrogen, and sulfur isotope analysis. J. Anthropol. Archaeol. 48, 28-45. doi: 10.1016/j.jaa.2017.05.006

Cheung, C., Zhang, H., Hepburn, J. C., Yang, D. Y., and Richards, M. P. (2019). Stable isotope and dental caries data reveal abrupt changes in subsistence economy in ancient China in response to global climate change. PLoS ONE 14:e0218943. doi: 10.1371/journal.pone.0218943

Cui, L. L., Hu, J. F., and Wang, X. (2019). Spatiotemporal evolution of $\mathrm{C} 3 / \mathrm{C} 4$ vegetation and its controlling factors in southern China since the last glacial maximum. Sci. China Earth Sci. 62, 1256-1268. doi: 10.1007/s11430-018-9225-9

Cui, L. L., Wang, X., Shen, J., and Ding, Z. L. (2015). Changes in distribution and compound-specific carbon isotope compositions of $n$-alkanes as recorded in Lugu Lake sediments from Southwestern China since Last Glacial Maximum and implications for paleovegetation evolution (in Chinese with English Abstract). Quat. Sci. 35, 871-880. doi: 10.11928/j.issn.1001-7410.2015.04.09

Dal Martello, R., Li, X. R., and Fuller, D. Q. (2021). Two-season agriculture and irrigated rice during the Dian: radiocarbon dates and archaeobotanical remains from Dayingzhuang, Yunnan, Southwest China. Archaeol. Anthropol. Sci. 13. doi: 10.1007/s12520-020-01268-y

Dal Martello, R., Min, R., Stevens, C., Higham, C., Higham, T., and Qin, L., et al. (2018). Early agriculture at the crossroads of China and Southeast Asia: Archaeobotanical evidence and radiocarbon dates from Baiyangcun, Yunnan. J. Archaeol. Sci. Rep. 20, 711-721. doi: 10.1016/j.jasrep.2018. 06.005

d'Alpoim Guedes, J., Lu, H. L., Li, Y. X., Spengler, R. N., Wu, X. H., and Aldenderfer, M. S. (2014). Moving agriculture onto the Tibetan plateau: the archaeobotanical evidence. Archaeol. Anthropol. Sci., 6, 255-269. doi: 10.1007/s12520-013-0153-4

DeNiro, M. J. (1985). Postmortem preservation and alteration of in vivo bone collagen isotope ratios in relation to palaeodietary reconstruction. Nature 317, 806-809. doi: 10.1038/317806a0

Dong, G. H., Li, R., Lu, M. X., Zhang, D. J., and James, N. (2020). Evolution of human-environmental interactions in China from the Late Paleolithic to the Bronze Age. Prog. Phys. Geogr. Earth Environ. 44, 233-250. doi: 10.1177/0309133319876802

Dong, G. H., Li, T., Zhang, S. J., Ren, L. L., Li, R., Li, G. Q., et al. (2021). Precipitation in surrounding mountains instead of lowlands facilitated the prosperity of ancient civilizations in the eastern Qaidam Basin of the Tibetan Plateau. Catena 203:105318. doi: 10.1016/j.catena.2021.105318

Dong, Y., Morgan, C., Chinenov, Y., Zhou, L. G., Fan, W. Q., and Ma, X. L., et al. (2017). Shifting diets and the rise of male-biased inequality on the Central Plains of China during Eastern Zhou. Proc. Natl. Acad. Sci. U.S.A. 114, 932-937. doi: $10.1073 /$ pnas.1611742114

Fan, Y. (2007). A Study on the Floristic Types of Bronze Culture in Yunnan Province (in Chinese). Sichuan Cultural Relics, 64-73.
Gao, Y., Dong, G. H., Yang, X. Y., and Chen, F. H. (2020). A review on the spread of prehistoric agriculture from southern China to mainland Southeast Asia. Sci. China Earth Sci. 63, 615-625. doi: 10.1007/s11430-019-9552-5

Hanks, B., Miller, A. V., Judd, M., Epimakhov, A., Razhev, D., and Privat, K. (2018). Bronze Age diet and economy: New stable isotope data from the Central Eurasian steppes (2100-1700 BC). J. Archaeol. Sci. 97, 14-25. doi: 10.1016/j.jas.2018.06.006

He, J. M. (2003). A preliminary study on regional systems of Bronze cultures in Yunnan (in Chinese with English Abstract). [master's thesis] [Shaanxi]: Northwest University.

Hou, L. L., Wang, N., Lü, P., Hu, Y. W., Song, G. D., and Wang, C. S. (2012). Transition of human diets and agricultural economy in Shenmingpu Site, Henan, from the Warring States to Han Dynasties. Sci. China Earth Sci. 55, 975-982. doi: 10.1007/s11430-012-4409-0

Hou, Y. F., Campbell, R., Zhang, Y., and Li, S. T. (2019). Animal use in a Shang Village: the Guandimiao zooarchaeological assemblage. Int. J. Osteoarchaeol. 29, 335-345. doi: 10.1002/oa.2745

Hu, Y. W., Wang, S. G., Luan, F. S., Wang, C. S., and Richards, M. P. (2008). Stable isotope analysis of humans from Xiaojingshan site: implications for understanding the origin of millet agriculture in China. J. Archaeol. Sci. 35, 2960-2965. doi: 10.1016/j.jas.2008.06.002

Isaakidou, V., and Halstead, P. (2018). "Carcasses, ceramics and cooking in Makriyalos I: towards an integrated approach to human diet and commensality in Late Neolithic northern Greece," in Social Dimensions of Food in the Prehistoric Balkans, ed. Ivanova, M., Athanassov, B., Petrova, V., Takorova, D., and Stockhammer, P.W. (Oxford: Oxbow Books), 66-85. doi: $10.2307 /$ j.ctvh1dsx3.8

Jiang, Z. L., and Wu, J. (2011). A Preliminary Research on the Jinlinshan Cemetery (in Chinese with English Abstract). Res. China's Front. Archaeol. 208-214.

Jin, H. T., Liu, X., Min, R., Li, X. R., and Wu, X. H. (2014). A study on flotation result of plant remains in the dadunzi site of Yuanmou, Yunan (in Chinese with English Abstract). Jianghan Archaeol. 132, 109-114.

Jin, Z. Z. (1999). The floristic study on seed plants in the dry-hot valleys in Yunnan and Sichuan (in Chinese). Guihaia 19, 1-14.

Jin, Z. Z., and Ou, X. K. (2000). Vegetation in dry-hot valleys of Yuanjiang, Nujiang, Jinshajiang, and Lancangjiang River (in Chinese). Kunming: Yunnan University Press and Yunnan Science and Technology Press.

Kohn, M. J. (1999). You are what you eat. Science 283, 335-336 doi: $10.1126 /$ science.283.5400.335

Lan, D. (2017). Isotope analysis on Human and Animal's Bone Unearthed from Zaoshugounao Site in Chunhua County, Shaanxi Province (in Chinese with English Abstract). [master's thesis] [Shaanxi]: Northwestern University.

Li, H. M., Zuo, X. X., Kang, L. H., Ren, L. L., Liu, F. W., Liu, H. G., et al. (2016). Prehistoric agriculture development in the Yunnan-Guizhou Plateau, southwest China: archaeobotanical evidence. Sci. China Earth Sci. 59, 1562-1573. doi: 10.1007/s11430-016-5292-x

Li, P. R., Meng, G. T., Fang, X. J., and Zeng, J. M. (2009). Flora of seed plants in Wuding county, Yunnan (in Chinese with English Abstract). J. Northeast For. Univ. 37, 106-108

Li, X., Zhang, S. J., Lu, M. X., Qiu, M. H., Wen, S. Q., and Ma, M. M. (2020). Dietary shift and social hierarchy from the Proto-Shang to Zhou Dynasty in the Central Plains of China. Environ. Res. Lett. 15:035002. doi: 10.1088/1748-9326/ab6783

Li, X. R., and Liu, X. (2016). Flotation report on the analysis on the archaeobotanical remains from the site of Guangfentou, Jiangchuan, Yunnan (in Chinese). Agric. Archaeol. 3, 20-27.

Ling, X., Chen, L., Tian, Y. Q., Li, Y., Zhao, C. C., and Hu, Y. W. (2010a). Carbon and nitrogen stable isotopic analysis on human bones from the qin tomb of sunjianantou site, Fengxiang, Shaanxi Province (in Chinese with English Abstract). Acta Anthropol. Sin. 29, 54-61.

Ling, X., Wang, W. S., Chen, L., Sun, L. J., and Hu, Y. W. (2010b). Stable Isotope Analysis of Qin Human Bones from Jianhe Cemetery in Baoji City, Shaanxi Province (in Chinese with English Abstract). Archaeol. Cultural Relics, 95-98.

Liu, H. G. (2016). Human activities and agriculture resources utilization from Paleolithic to Bronze Age in northwest Yunnan province (in Chinese with English Abstract). [dissertation thesis]. [Lanzhou]: Lanzhou University.

Ma, M., Dong, G., Liu, X., Lightfoot, E., Chen, F., Wang, H., et al. (2015). Stable isotope analysis of human and animal remains at the Qijiaping site in middle Gansu, China. Int. J. Osteoarchaeol. 25, 923-934. doi: 10.1002/oa.2379 
Ma, M. M., Dong, G. H., Jia, X., Wang, H., Cui, Y. F., and Chen, F. H. (2016). Dietary shift after $3600 \mathrm{cal} \mathrm{yr} \mathrm{BP}$ and its influencing factors in northwestern China: evidence from stable isotopes. Quat. Sci. Rev. 145, 57-70. doi: 10.1016/j.quascirev.2016.05.041

Nelson, D. M., Hu, F. S., Tian, J., Stefanova, I., and Brown, T. A. (2004). Response of C3 and C4 plants to middle-Holocene climatic variation near the prairie-forest ecotone of Minnesota. Proc. Natl. Acad. Sci. U.S.A. 101, 562-567. doi: $10.1073 /$ pnas. 0307450100

Nie, X., Chen, Q. H., and Wu, L. L. (2008). Method of showing the grade of terrain broken based on the DEM. Geospatial Inf. 6, 62-64. doi: 10.3969/j.issn.1672-4623.2008.06.020

$\mathrm{Ou}, \mathrm{X} . \mathrm{K}$. (1994). Resource plants and their ecological characteristics in the dry- hot valley of the Jinshajiang River (in Chinese). J. Plant Resour. Environ. 3, 42-46.

Pei, D. M., Hu, Y. W., Yang, Y. M., Zhang, Q. C., Zhang, G. W., Tian, J. W., et al. (2008). Paleodietary analysis of humans from the neiyangyuan site of Xiangning, Shanxi Province (in Chinese with English Abstract). Acta Anthropol. Sin. 27, 379-384.

Ramsey, C. B. (2017). Methods for summarizing radiocarbon datasets. Radiocarbon 59, 1809-1833. doi: 10.1017/RDC.2017.108

Reimer, P. J., Austin, W. E., Bard, E., Bayliss, A., Blackwell, P. G., Ramsey, C. B., et al. (2020). The IntCal20 Northern Hemisphere radiocarbon age calibration curve (0-55 cal kBP). Radiocarbon 62, 725-757. doi: 10.1017/RDC.2020.41

Ren, L. L., Dong, G. H., Liu, F. W., d'Alpoim-Guedes, J., Flad, R. K., Ma, M. M., et al. (2020). Foraging and farming: archaeobotanical and zooarchaeological evidence for Neolithic exchange on the Tibetan Plateau. Antiquity 94, 637-652. doi: $10.15184 /$ aqy.2020.35

Ren, L. L., Li, X., Kang, L. H., Brunson, K., Liu, H. G., Dong, W. M., et al. (2017). Human paleodiet and animal utilization strategies during the Bronze Age in northwest Yunnan Province, southwest China. PLoS ONE 12:e0177867. doi: 10.1371/journal.pone.0177867

Richards, M. P. (2015). Stable isotope analysis of bone and teeth as a means for reconstructing past human diets in Greece. Hesperia Suppl. 49, 15-23. Available online at: www.jstor.org/stable/24637309

Richards, M. P., and Hedges, R. E. M. (1999). Stable isotope evidence for similarities in the types of marine foods used by Late Mesolithic humans at sites along the Atlantic coast of Europe. J. Archaeol. Sci. 26, 717-722. doi: 10.1006/jasc. 1998.0387

Shi, H. Y., and Chen, J. (2018). Characteristics of climate change and its relationship with land use/cover change in Yunnan Province, China. Int. J. Climatol. 38, 2520-2537. doi: 10.1002/joc.5404

Sun, W. (2019). Carbon and nitrogen stable isotope of the human and animal bones from the Hengshui cemetery (in Chinese with English Abstract). [master's thesis] [Shanxi]: Shanxi University.

Svyatko, S. V., Schulting, R. J., Mallory, J., Murphy, E. M., Reimer, P. J., Khartanovich, V. I., et al. (2013). Stable isotope dietary analysis of prehistoric populations from the Minusinsk Basin, Southern Siberia, Russia: a new chronological framework for the introduction of millet to the eastern Eurasian steppe. J. Archaeol. Sci. 40, 3936-3945. doi: 10.1016/j.jas.2013.05.005

Tang, M., Wang, X. Y., Hou, K., and Hou, L. L. (2018). Carbon and nitrogen stable isotope of the human bones from the Xiaonanzhuang cemetery, Jinzhong, Shanxi: A preliminary study on the expansion of wheat in ancient Shanxi, China (in Chinese with English Abstract). Acta Anthropol. Sin. 37, 318-330. doi: 10.16359/j.cnki.cn11-1963/q.2018.0013

Tao, D. W., Zhang, G. W., Zhou, Y. W., and Zhao, H. Z. (2020). Investigating wheat consumption based on multiple evidences: Stable isotope analysis on human bone and starch grain analysis on dental calculus of humans from the Laodaojing cemetery, Central Plains, China. Int. J. Osteoarchaeol. 30, 594-606. doi: 10.1002/oa.2884

Wang, Q. (2014). Plant Macrofossil Analysis of Xueshan Site in Chengjiang County of Yunnan Province (in Chinese with English Abstract). [master's thesis] [Shandong]: Shandong University.

Ward, J. K., Tissue, D. T., Thomas, R. B., and Strain, B. R. (1999). Comparative responses of model $\mathrm{C} 3$ and $\mathrm{C} 4$ plants to drought in low and elevated $\mathrm{CO} 2$. Global Change Biol. 5, 857-867. doi: 10.1046/j.1365-2486.1999.00270.x

Wu, X. T., Hein, A., Zhang, X. X., Jin, Z. Y., Wei, D., Huang, F., et al. (2019). Resettlement strategies and Han imperial expansion into southwest China: a multimethod approach to colonialism and migration. Archaeol. Anthropol. Sci. 11, 6751-6781. doi: 10.1007/s12520-019-00938-w
Xiao, X. Y., Haberle, S. G., Li, Y. L., Liu, E., Shen, J., Zhang, E., et al. (2018). Evidence of Holocene climatic change and human impact in northwestern Yunnan Province: High-resolution pollen and charcoal records from Chenghai Lake, southwestern China. Holocene 28, 127-139. doi: $10.1177 / 0959683617715692$

Xiao, X. Y., Haberle, S. G., Shen, J., Yang, X. D., Han, Y., Zhang, E., et al. (2014). Latest Pleistocene and Holocene vegetation and climate history inferred from an alpine lacustrine record, northwestern Yunnan Province, southwestern China. Quat. Sci. Rev. 86, 35-48. doi: 10.1016/j.quascirev.2013.12.023

Xiao, X. Y., Yao, A., Hillman, A., Shen, J., and Haberle, S. G. (2020). Vegetation, climate and human impact since $20 \mathrm{ka}$ in central Yunnan Province based on high-resolution pollen and charcoal records from Dianchi, southwestern China. Quat. Sci. Rev. 236:106297. doi: 10.1016/j.quascirev.2020.106297

Xue, Y. N. (2010). Pilot study of plant remains about Haimenkou site in Jianchuan County, Yunnan Province (in Chinese with English Abstract). [master's thesis] [Beijing]: Peking University.

Yang, L. X. (2006). Status Quo of Afforestation in Dry \&Hot River Valley of Wudin County and Countermeasures for the Development (in Chinese with English Abstract). For. Inventory Plann. 31, 101-105. doi: 10.3969/j.issn.1671-3168.2006.06.024

Yang, W. (2016). The analysis of charred plant remains at Hebosuo site and Yubeidi site in Yunnan province(in Chinese with English Abstract). [master's thesis]. [Shandong]: Shandong University.

Yao, A., Jiang, Z. L., Chen, X. X., and Liang, Y. (2015). Bronze age wetland/scapes: complex political formations in the humid subtropics of southwest China, 900-100 BC. J. Anthropol. Archaeol. 40, 213-229. doi: 10.1016/j.jaa.2015.08.005

Yuan, J. (2015). Zooarchaeology in China (in Chinese). Beijing: Cultural Relics Press.

Yunnan Institute of Cultural Relics and Archaeology (2019). Jiangxifen site, Wuding, Yunnan, China (in Chinese). Available online at: http://www.ynkgs. $\mathrm{com} / \mathrm{html} /$ discover $/ 20190828103752 . \mathrm{htm}$ (accessed January 1, 2021).

Zhang, G. W., Jiang, L. P., Hu, Y. W., Si, Y., Lv, P., Song, G. D., et al. (2015). $\mathrm{C}, \mathrm{N}$ stable isotope analysis of human and animal bones at Tashan site in Zhejiang (in Chinese with English Abstract). Huaxia Archaeol. 2, 138-146. doi: 10.16143/j.cnki.1001-9928.2015.02.015

Zhang, J. Y., Xu, Y., Su, C. J., and Liu, X. L. (2005). Research progress on vegetation restoration in the dry-hot valleys of the Jinsha River (in Chinese with English Abstract). Res. Soil Water Conserv. 12, 101-104.

Zhang, N. M., Dong, G. H., Yang, X. Y., Zuo, X. X., Kang, L. H., Ren, L. L., et al. (2017). Diet reconstructed from an analysis of plant microfossils in human dental calculus from the Bronze Age site of Shilinggang, southwestern China. J. Archaeol. Sci. 83, 41-48. doi: 10.1016/j.jas.2017.06.010

Zhang, Q. C. (2011). Preliminary analysis of stable isotopes of human bones unearthed from Jinlianshan Cemetery in Chengjiang County, Yunnan (in Chinese). Archaeology 30-33.

Zhang, X. X., Burton, J., Jin, Z. Y., Xiao, M. H., Fan, A. C., and Xu, J. F. (2014). Isotope studies of human remains from Mayutian, Yunnan Province, China. J. Archaeol. Sci. 50, 414-419. doi: 10.1016/j.jas.2014. 08.001

Zhao, Z. J. (2014). The process of origin of agriculture in China: Archaeological evidence from flotation results (in Chinese). Quat. Sci. 34, 73-84. doi: 10.3969/j.issn.1001-7410.2014.01.10

Zheng, X., Zhang, H. C., Ming, Q. Z., Chang, F. Q., Meng, H. W., Zhang, W. X., et al. (2014). Vegetational and environmental changes since $15 \mathrm{ka}$ B.P. recorded by lake Lugu in the southwest monsoon domain region (in Chinese with English Abstract). Quat. Sci. 34, 1314-2014. doi: 10.3969/j.issn.1001-7410.2014.06.21

Zhou, L. G., and Garvie-Lok, S. J. (2015). Isotopic evidence for the expansion of wheat consumption in northern China. Archaeol. Res. Asia 4, 25-35. doi: 10.1016/j.ara.2015.10.001

Zhou, L. G., Garvie-Lok, S. J., Fan, W. Q., and Chu, X. L. (2017) Human diets during the social transition from territorial states to empire: stable isotope analysis of human and animal remains from BCE to 220 CE on the central plains of china. J. Archaeol. Sci. Rep. 11, 211-223. doi: 10.1016/j.jasrep.2016.11.019

Zhou, X. Y., Li, X. Q., Dodson, J., and Zhao, K. L. (2016). Rapid agricultural transformation in the prehistoric Hexi corridor, China. Quat. Int. 426, 33-41. doi: 10.1016/j.quaint.2016.04.021 
Conflict of Interest: The authors declare that the research was conducted in the absence of any commercial or financial relationships that could be construed as a potential conflict of interest.

The handling editor declared a past co-authorship with one of the authors LR and MM.
Copyright (C) $2021 \mathrm{Lu}, \mathrm{Li}, \mathrm{Wei}, \mathrm{Lu}$, Ren and Ma. This is an open-access article distributed under the terms of the Creative Commons Attribution License (CC BY).

The use, distribution or reproduction in other forums is permitted, provided the original author(s) and the copyright owner(s) are credited and that the original publication in this journal is cited, in accordance with accepted academic practice. No use, distribution or reproduction is permitted which does not comply with these terms. 